\title{
Slight temperature changes cause rapid transcriptomic responses in Trypanosoma cruzi metacyclic trypomastigotes
}

Lissa Cruz-Saavedra' ${ }^{1}$ Marina Muñoz ${ }^{1}$, Luz Helena Patiño' ${ }^{1}$ Gustavo A. Vallejo², Felipe Guhl ${ }^{3}$ and Juan David Ramírez ${ }^{1 *}$ (B)

\begin{abstract}
Background: Severe changes in temperature can affect the behavior and ecology of some infectious agents. Trypanosoma cruzi is a protozoan that causes Chagas disease. This parasite has high genetic variability and can be divided into six discrete typing units (DTUs). Trypanosoma cruzi also has a complex life-cycle, which includes the process of metacyclogenesis when non-infective epimastigote forms are differentiated into infective metacyclic trypomastigotes (MT). Studies in triatomines have shown that changes in temperature also affect the number and viability of MT.
\end{abstract}

Methods: The objective of this study was to evaluate how temperature affects the transcriptional profiles of T. cruzi I and II (TCl and TCII) MT by exposing parasites to two temperatures $\left(27^{\circ} \mathrm{C}\right.$ and $\left.28^{\circ} \mathrm{C}\right)$ and comparing those to normal culture conditions at $26^{\circ} \mathrm{C}$. Subsequently, RNA-seq was conducted and differentially expressed genes were quantified and associated to metabolic pathways.

Results: A statistically significant difference was observed in the number of MT between the temperatures evaluated and the control, Tcll DTU was not strongly affected to exposure to high temperatures compared to Tcl. Similar results were found when we analyzed gene expression in this DTU, with the greatest number of differentially expressed genes being observed at $28^{\circ} \mathrm{C}$, which could indicate a dysregulation of different signaling pathways under this temperature. Chromosome analysis indicated that chromosome 1 harbored the highest number of changes for both DTUs for all thermal treatments. Finally, gene ontology (GO) analyses showed a decrease in the coding RNAs involved in the regulation of processes related to the metabolism of lipids and carbohydrates, the evasion of oxidative stress, and proteolysis and phosphorylation processes, and a decrease in RNAs coding to ribosomal proteins in Tcl and Tcll, along with an increase in the expression of surface metalloprotease GP63 in Tcll.

Conclusions: Slight temperature shifts lead to increased cell death of metacyclic trypomastigotes because of the deregulation of gene expression of different processes essential for the Tcl and Tcll DTUs of T. cruzi.

Keywords: Trypanosoma cruzi, DTUs, Temperature, Metacyclic trypomastigotes, RNAseq, Transcriptomic

\footnotetext{
*Correspondence: juand.ramirez@urosario.edu.co

${ }^{1}$ Grupo de Investigaciones Microbiológicas-UR (GIMUR), Departamento

de Biología, Facultad de Ciencias Naturales, Universidad del Rosario,

Bogotá, Colombia

Full list of author information is available at the end of the article
}

\section{Background}

It is estimated that during the last 130 years there has been an increase of $0.85{ }^{\circ} \mathrm{C}$ in the global temperature, with the biggest changes observed during the last few decades [1]. Temperature changes affect host-pathogen interactions, vector distributions, transmission, and in

c) The Author(s) 2020. This article is licensed under a Creative Commons Attribution 4.0 International License, which permits use, sharing, adaptation, distribution and reproduction in any medium or format, as long as you give appropriate credit to the original author(s) and the source, provide a link to the Creative Commons licence, and indicate if changes were made. The images or other third party material in this article are included in the article's Creative Commons licence, unless indicated otherwise in a credit line to the material. If material is not included in the article's Creative Commons licence and your intended use is not permitted by statutory regulation or exceeds the permitted use, you will need to obtain permission directly from the copyright holder. To view a copy of this licence, visit http://creativeco mmons.org/licenses/by/4.0/. The Creative Commons Public Domain Dedication waiver (http://creativecommons.org/publicdomain/ zero/1.0/) applies to the data made available in this article, unless otherwise stated in a credit line to the data. 
some cases even the life-cycle of pathogens, mainly for vector-borne diseases such as dengue, malaria, leishmaniasis, and Chagas disease [2-11].

Triatomines (Hemiptera: Reduviidae) are the vectors of Chagas disease, an endemic pathology caused by Trypanosoma cruzi. Studies analyzing the effects of temperature shifts on the distribution of Chagas disease vectors have shown variable results, ranging from a possible decrease in the number of human infections to an increased risk of infection $[5,12,13]$. Studies on the impact of temperature shifts $\left(28{ }^{\circ} \mathrm{C}\right.$ and $\left.30{ }^{\circ} \mathrm{C}\right)$ on the life-cycle of Rhodnius prolixus, a main vector of Chagas disease, have found that an increase in temperature decreases the transmission of the parasite, increases the ratio of feeding and reproduction, and affects the process of metacyclogenesis in the vector in the first 10 days of infection, when $26{ }^{\circ} \mathrm{C}$ is used as a control [14]. Similarly, studies of the phenol-oxidase system in the vector, which is involved in immunity against invading pathogens, have shown decreased levels at high temperatures, thus affecting both T. cruzi infection and vector survival [15]. This suggests that triatomine biology and the parasite lifecycle are directly affected by slight temperature shifts.

Trypanosoma cruzi shows high genetic variability and is classified into six discrete typing units (DTUs), associated with different epidemiological cycles, hosts, vectors, and clinical manifestations [16, 17]. In addition, this parasite has a complex life-cycle involving four stages during its passage between mammalian hosts such as humans and triatomine vectors. One of the most important steps in the life-cycle of $T$. cruzi occurs in the rectal ampulla of the vector and involves the transformation of non-infective replicative epimastigote forms into infective metacyclic trypomastigotes (MT) [18]. This process is called metacyclogenesis and involves morphological, biochemical, genetic, and transcriptional changes essential for progression of the parasite's life-cycle [18-20]. The factors that promote metacyclogenesis are yet to be fully elucidated; however, nutritional stress increases the levels of adenylate cyclase expression and cAMP concentrations stimulate the expression of genes involved in autophagy, which is essential for the progression of this process. Some metabolic changes that have been detected in metacyclogenesis are related to the presence of oxidized proteins, the activation of enzymes involved in the metabolism of carbon and nitrogen as a source of energy, and the activation of mitochondrial enzymes, such as cytochrome, in response to nutritional stress [21-23]. Some of the changes in the parasite during this process are related to structural modifications of the kinetoplast, elongation of the nucleus, and an increase in heterochromatin, together these changes relate to the decrease in mRNA expression in MT forms [18, 24]. The success of the metacyclogenesis process depends on the expression of certain specific genes, such as those encoding methionine peptidase I (Met I), surface metalloprotease GP82, surface metalloprotease GP90, and MT-specific proteins, as well as other genes such as the Tclmp4 gene associated with a ribonucleoprotein involved in the processing of the S40 subunit, which is important in progression of the cell-cycle $[25,26]$. Transcriptomic analysis using RNAseq technology has been useful in understanding the gene remodeling that occurs in T. cruzi during infection, in identifying genes expressed differentially between the three stages of this parasite, and in evaluating the gene profiles between virulent and non-virulent clones [2731]. However, until now, the transcriptional profiles of T. cruzi have not been evaluated when MT are exposed to different temperatures. Therefore, the objective of this study was to assess whether slight and short-term changes in temperature affect the gene transcription of $T$. cruzi MT.

\section{Methods \\ Epimastigote culture}

Cultures of epimastigotes of the strains MHOM/CO/04/ MG (TcI) and MHOM/BR/53/Y (TcII) were maintained by weekly passage in liver infusion tryptose (LIT) medium supplemented with $10 \%$ fetal bovine serum. These strains were selected as these have been previously used in in vivo studies in murine models and triatomines, they are fully characterized and provide a suitable set of biological strains for in vitro studies [14]. For verification of the DTU, DNA extraction was performed from cultures of epimastigotes in logarithmic phase for both strains using the DNeasy kit (Cat. \# 69504; Qiagen, Hilden, Germany), followed by conventional PCR directed to the splicedleader intergenic region (SL-IR) as reported elsewhere [32]. The obtained products were subjected to electrophoresis on a $2 \%$ agarose gel, with expected band sizes of $300 \mathrm{bp}$ for TcII and $350 \mathrm{bp}$ for TcI.

\section{Calculation of MTs per day}

To determine the day at which the number of MTs emerged, we calculated the number of MTs as previously described [33]. Epimastigotes in exponential growth phase, genotyped previously as TcI (MHOM/CO/04/ MG) and TcII (MHOM/BR/53/Y), were washed twice with phosphate-buffered saline $(1 \times \mathrm{PBS})$ and centrifuged at $10,000 \times \mathrm{rpm}$, then $1 \times 10^{7}$ epimastigotes were cultivated in LIT medium supplemented with $5 \%$ fetal bovine serum at temperatures of $26^{\circ} \mathrm{C}, 27^{\circ} \mathrm{C}$ and $28^{\circ} \mathrm{C}$. These temperatures were selected based on an estimated temperature increase of $0.85{ }^{\circ} \mathrm{C}$ during recent decades and a previous report in $R$. prolixus [14]. To avoid a bias related to a possible inadequate initial concentration 
of epimastigotes, all tests were carried out from the same initial inoculum and placed in different incubators according to the required temperature. The cultures were kept for 10 days, considering that we wanted to obtain pure MT cultures. The verification of temperature maintenance in the incubators was carried out twice a day during the entire study period. The concentration of parasites was calculated using a Neubauer chamber, in order to determine the epimastigotes and trypomastigotes that were viable; the mobility of parasites was used as a discrimination parameter and only mobile forms were included in the count. The number of epimastigotes (EP) and metacyclic trypomastigotes (MT) was determined microscopically on slides fixed with $100 \%$ methanol with $10 \%$ Giemsa stain. For each slide, 300 fields were analyzed under an optical microscope $(40 \times)$. Three biological replicates for each experiment were included, as well as three technical replicates for each biological replicate to decrease any operator errors.

\section{Statistical analysis}

The data relating to the concentration of parasites and the determination of stages were tabulated in Microsoft Excel. The determination of stages was normalized as a percentage that included two factors: the percentage of MT and the percentage of EP. These data were applied to the concentration of parasites to determine the specific concentration for each morphological stage in each individual experiment. To evaluate whether the data showed a normal distribution, a Shapiro-Wilk test was carried out, followed by (provided the obtained data did not follow a normal distribution) a Kruskall-Wallis test and the analysis of Dunn's multiple comparisons to determine the day of emergence of metacyclic forms (EMD). This day was selected as the first day when statistically significant changes were observed in the concentration of MT compared with the control (day 0). The data were also used to generate a calculation of MTs per day. Finally, the comparison between DTUs was performed using a non-parametric Friedman test followed by an analysis of multiple comparisons. All analyses were performed using GraphPad Prism 7.4 software using $P<0.05$ as the cut-off for significance.

\section{Purification of metacyclic trypomastigotes}

To evaluate the expression of MT genes during EMD when the parasites were subjected to different temperatures $\left(26^{\circ} \mathrm{C}, 27{ }^{\circ} \mathrm{C}\right.$ and $\left.28{ }^{\circ} \mathrm{C}\right)$, RNA extraction from TcI (MHOM/CO/04/MG) and TcII (MHOM/BR/53/Y) was performed. As we previously reported [33], cultures of $T$. cruzi contain a mix of EP and MT stages during EMD. To obtain a pure MT sample, we developed sepharose ion exchange chromatography according to our previously reported protocol [33]. After which, the samples were washed twice with $1 \times$ PBS and the stage was verified under a microscope.

\section{RNA extraction and sequencing}

In order to stabilize the MT after purification by means of sepharose-DEAE resin chromatography, the MT obtained were washed twice with $1 \times$ PBS, and incubated in LIT medium without supplements for $2 \mathrm{~h}$. MT purified by sepharose ion exchange chromatography were subjected to RNA extraction. The RNA was extracted from 24 samples (i.e. two DTUs at three temperatures, with two biological replicates and two technical replicates) using a RNeasy Plus Mini Kit (Qiagen) following the manufacturer's protocol. The quality of the RNA obtained was evaluated on an agarose gel and the concentration, as well as other parameters such as the 260/280 index and the 230/260 index, were measured by nanodrop spectrophotometry. The RNAs that showed typical RNA bands, had concentrations higher that $1 \mathrm{mg} / \mathrm{ml}$, and a 260/280 index close to 2 were selected for total RNA sequencing.

The selected RNAs were sent to Novogene Bioinformatics Technology Co., Ltd. (Beijing, China) for sequencing using the Illumina HiSeq X-TEN platform. The strand-specific TrueSeq RNAseq Library Prep with an insert size of 350 bp was selected to prepare the RNA libraries, and the size of each read was $2 \times 150 \mathrm{bp}$. The read quality was verified using fastqc software (http:// www.bioinformatics.babraham.ac.uk/projects/fastqc/). In summary, parameters such as per base quality score, per base sequence GC content, Kmer content (among others) were evaluated.

\section{Mapping and transcript quantification}

The raw sequence reads, for the 24 transcriptomes included in this study, had an average of 70,630,112 bases and a standard deviation of 20,976,808.33 bases. The results for each of the treatments and replicates are available in Additional file 1: Table S1.

The fasta file for the T. cruzi Sylvio X10-1 genome was downloaded from the Eupath TriTryp database (https:// tritrypdb.org/tritrypdb/) and Bowtie version 2 software was used as a reference index (Additional file 2: Table S2). Then 24 paired-end samples were individually aligned using TopHat version v2.1.0 and default parameters [34]. Similarly, the gtf file deform annotated genome of T. cruzi Sylvio X10-1 was downloaded from the Eupath TriTryp database and was used to perform transcript assembly from the reads obtained from the alignment by TopHat (Additional file 2: Table S2). The software Cufflinks version v2.0.2 (http://cole-trapnell-lab.github.io/cufflinks/) was used for this task and the " $u$ " parameter (multi-read correlation) was included. Once the mapping process was 
completed, the union of the gff files obtained using the Cuffmerge tool of Cufflinks was made using the "g" and "s" options, and different files were created to analyze the differences in expression between replicates, different temperatures for the same DTU, and finally, between DTUs at the same temperature [34].

\section{Differential expression and ontology analysis}

Cuffdiff was used to evaluate the differential expression of genes between DTUs and temperatures [34]. The normalized expression was calculated using FPKM (fragments per kilobase of exon per million fragments mapped), and comparisons between genes expressed at $27{ }^{\circ} \mathrm{C}$ and $28{ }^{\circ} \mathrm{C}$ and the $26{ }^{\circ} \mathrm{C}$ control were made for each of the DTUs. Genes that presented a Q-value ( $P$-value corrected) less than or equal to 0.05 were considered to be differentially expressed. The same protocol was followed to evaluate the differential expression between replicates of samples and DTUs for each of the temperatures. The CummeRbund software package in $\mathrm{R}$ was used to visualize the output files obtained from the Cuffdiff analysis and for the generation of graphs [35]. To make a biological inference and determine the protein products encoded for each of the DEGs, and to analyze the enzymes that could be encoded by these same genes, the list of upregulated and downregulated genes obtained by the statistical analysis of Cuffdiff were analyzed using the EupathDB TriTryp online tool (https://tritrypdb.org/tritrypdb/), and the lists of DEGs for each treatment were submitted. The output files were selected based on the analysis of the gene ontological terms (GO terms) for each of these genes, and the tables obtained were recorded in Microsoft Excel for further analysis [36, 37]. Dynamic tables were constructed to quantify the number of upregulated and downregulated genes for each of the GO terms and the results were used to construct graphs. Ten biological process GO terms with the greatest number of genes were selected.

\section{Results}

\section{Increase in temperature affects the emergence}

of metacyclic trypomastigotes in Trypanosoma cruzi I and II in vitro

The emergence of MT was evaluated in $T$. cruzi MHOM/CO/04/MG (TcI) and MHOM/BR/53/Y (TcII) cultures over 10 days (Fig. 1a). Nutritional stress is one of the main factors that promotes metacyclogenesis in T. cruzi, and previous studies have demonstrated the presence of MT in cultures grown in LIT medium when a high concentration of parasites was used as the inoculum. We used these previously described culture conditions and protocol to calculate the MT per day in this study [33]. No MT were observed on day 0 , but low concentrations of MT were detected from day 1 in most of the treatment conditions, except for TcI incubated at $27{ }^{\circ} \mathrm{C}$ (MT observed from day 2). The highest concentrations of MT $\left(6 \times 10^{8}\right.$ trypomastigotes $/ \mathrm{ml}$ on average) were observed on day 7 for TcI incubated at $26{ }^{\circ} \mathrm{C}$, whereas the concentration of MT for TcII under the same conditions was $2.8 \times 10^{8}$ trypomastigotes $/ \mathrm{ml}$ on day 8 (Fig.1b, c). The concentration of MT decreased at temperatures of $27^{\circ} \mathrm{C}$ and $28{ }^{\circ} \mathrm{C}$ for both DTUs, with a maximum of $6.0 \times 10^{7}$ and $1.7 \times 10^{7}$ trypomastigotes $/ \mathrm{ml}$ being detected, respectively, with the highest concentrations of MT observed on day 10 (Fig. 1a, b, e). Similar behavior was observed for TcII incubated at $27{ }^{\circ} \mathrm{C}$ and $28{ }^{\circ} \mathrm{C}$, with maximum concentrations of $8.5 \times 10^{7}$ and $1.3 \times 10^{7}$ trypomastigotes $/ \mathrm{ml}$ on day 10 (Fig. 1b, d, e). As previously mentioned, MT concentrations were higher for TcI compared with TcII in most of the experiments (Fig. 2c, d, e); however, we found the opposite behavior for TcII at $27^{\circ} \mathrm{C}$ on day 10 , with higher concentrations of MT compared with TcI at $27{ }^{\circ} \mathrm{C}$; despite this, no statistically significant difference was observed on this day. We performed normality analysis using the Shapiro-Wilk test for the data obtained from each of the treatments and the results showed that some samples did not follow a normal distribution. We therefore used non-parametric analysis for statistical evaluation of our data. To determine the day of emergence of metacyclic forms (EMD), we performed a Kruskall-Wallis test followed by an analysis of Dunn's multiple comparisons, using day 0 (0 trypomastigotes $/ \mathrm{ml}$ ) as the control. The EMD for the TcI cultured at $26{ }^{\circ} \mathrm{C}$ occurred 4 days post-culture (DPC), compared with $6 \mathrm{DPC}$ for TcII at the same temperature (Fig. 1b). When the temperature was increased to $27{ }^{\circ} \mathrm{C}$, the EMD occurred at $8 \mathrm{DPC}$ for TcI and $6 \mathrm{DPC}$ for TcII, and at $28{ }^{\circ} \mathrm{C}$, the EMD was 8 and $5 \mathrm{DPC}$ for TcI and TcII, respectively. Samples from the EMD were used for RNA extraction for each of the treatments (Fig. 1c, d, e). Differences between the temperatures and DTUs were analyzed by Friedman's non-parametric tests and the results revealed statistically significant differences between the treatments $(P<0.0001, d f=6)$. To analyze these differences in greater detail, Dunn's multiple comparisons were performed and no differences were detected between the DTUs treated at the same temperature. However, following KolmogorovSmirnov analysis, a difference between the TcI at $26^{\circ} \mathrm{C}$ and TcII at $26^{\circ} \mathrm{C}$ treatments was detected $(P=0.0233)$. Furthermore, a difference was detected between the parasites treated at $26{ }^{\circ} \mathrm{C}$ (control) and $28{ }^{\circ} \mathrm{C}$ for both DTUs $(P \leq 0.001)$. 


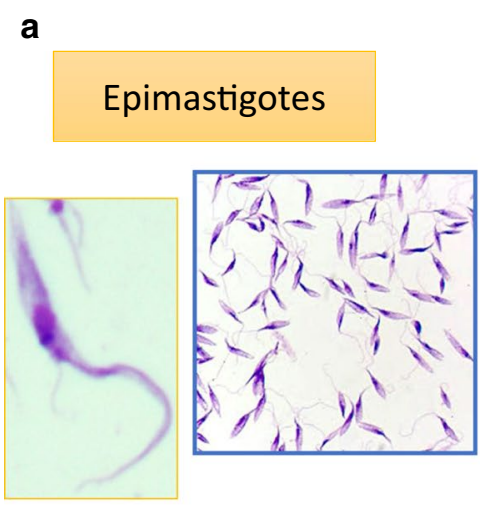

\title{
Emergence of metacyclic forms
}

\begin{tabular}{|l|c|c|c|c|c|c|c|c|c|c|}
\hline Days & $\mathbf{1}$ & $\mathbf{2}$ & $\mathbf{3}$ & $\mathbf{4}$ & $\mathbf{5}$ & $\mathbf{6}$ & $\mathbf{7}$ & $\mathbf{8}$ & $\mathbf{9}$ & $\mathbf{1 0}$ \\
\hline Parasite concentration & $\mathrm{x}$ & $\mathrm{x}$ & $\mathrm{x}$ & $\mathrm{x}$ & $\mathrm{x}$ & $\mathrm{x}$ & $\mathrm{x}$ & $\mathrm{x}$ & $\mathrm{x}$ & $\mathrm{x}$ \\
\hline \hline Determination of stages & $\mathrm{x}$ & $\mathrm{x}$ & $\mathrm{x}$ & $\mathrm{x}$ & $\mathrm{x}$ & $\mathrm{x}$ & $\mathrm{x}$ & $\mathrm{x}$ & $\mathrm{x}$ & $\mathrm{x}$ \\
\hline
\end{tabular}

b Calculation of metacyclic trypomastigotes

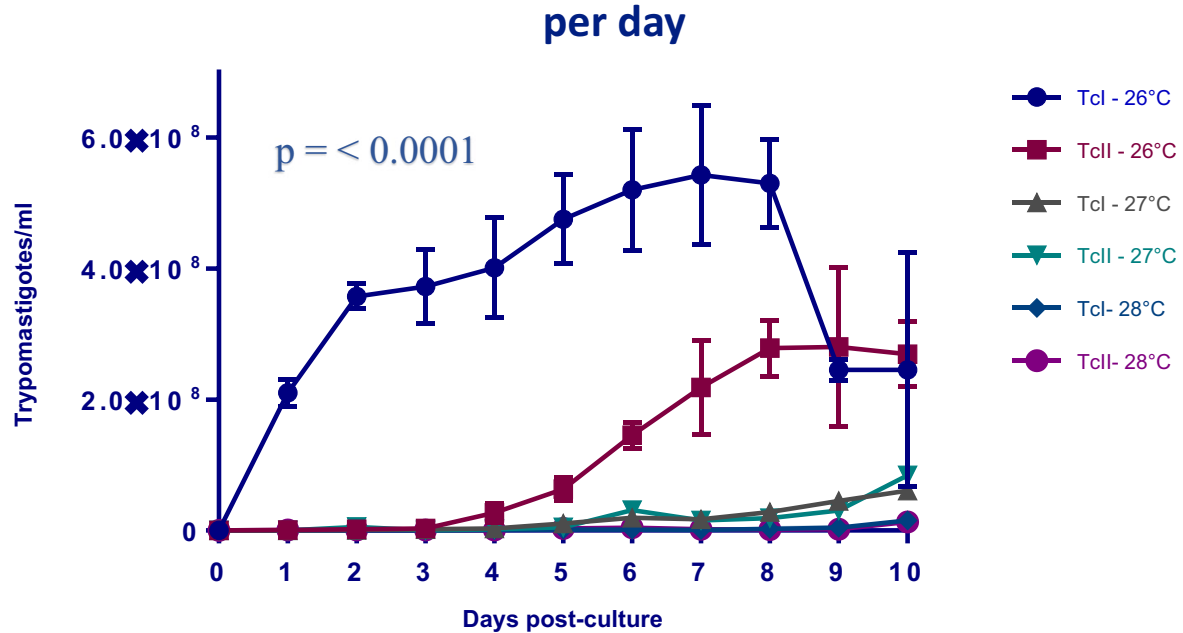

Metacyclic trypomastigotes
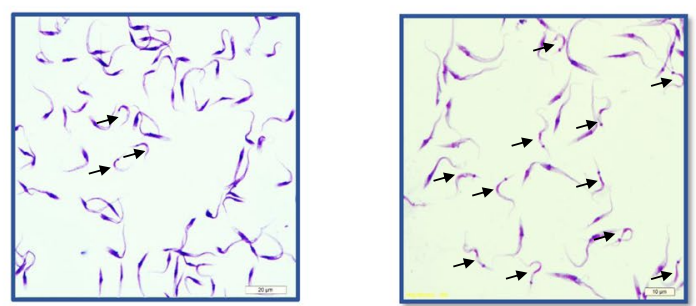

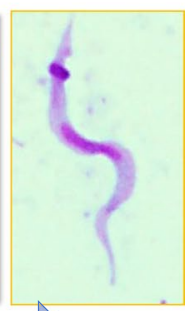

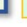

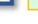


A total of 11,154 genes were compared for TcI at $26{ }^{\circ} \mathrm{C}$ and $27{ }^{\circ} \mathrm{C}$, and 11,185 genes were compared for TcI at $26{ }^{\circ} \mathrm{C}$ and $28{ }^{\circ} \mathrm{C}$. For TcII the comparison between $26{ }^{\circ} \mathrm{C}$ and $27{ }^{\circ} \mathrm{C}$ included 5884 and in the case of $26{ }^{\circ} \mathrm{C}$ and $28{ }^{\circ} \mathrm{C}$ the number of genes corresponded to 13,187 . On the other hand, the comparison between DTUs at $26{ }^{\circ} \mathrm{C}$ had 10,984 genes, for $27{ }^{\circ} \mathrm{C}$ there were 9300 genes, and finally, for $28^{\circ} \mathrm{C} 9777$ genes. Differential expression analysis revealed that the MT of TcI and TcII exposed to different temperatures showed differences in the expression of genes when compared with the control at $26^{\circ} \mathrm{C}$ by Cuffdiff analysis (Fig. 2a, b, Additional file 5: Table S3). Similarly, differences in gene expression were assessed for DTUs at each of the temperatures (Fig. 2c-e); however, a smaller

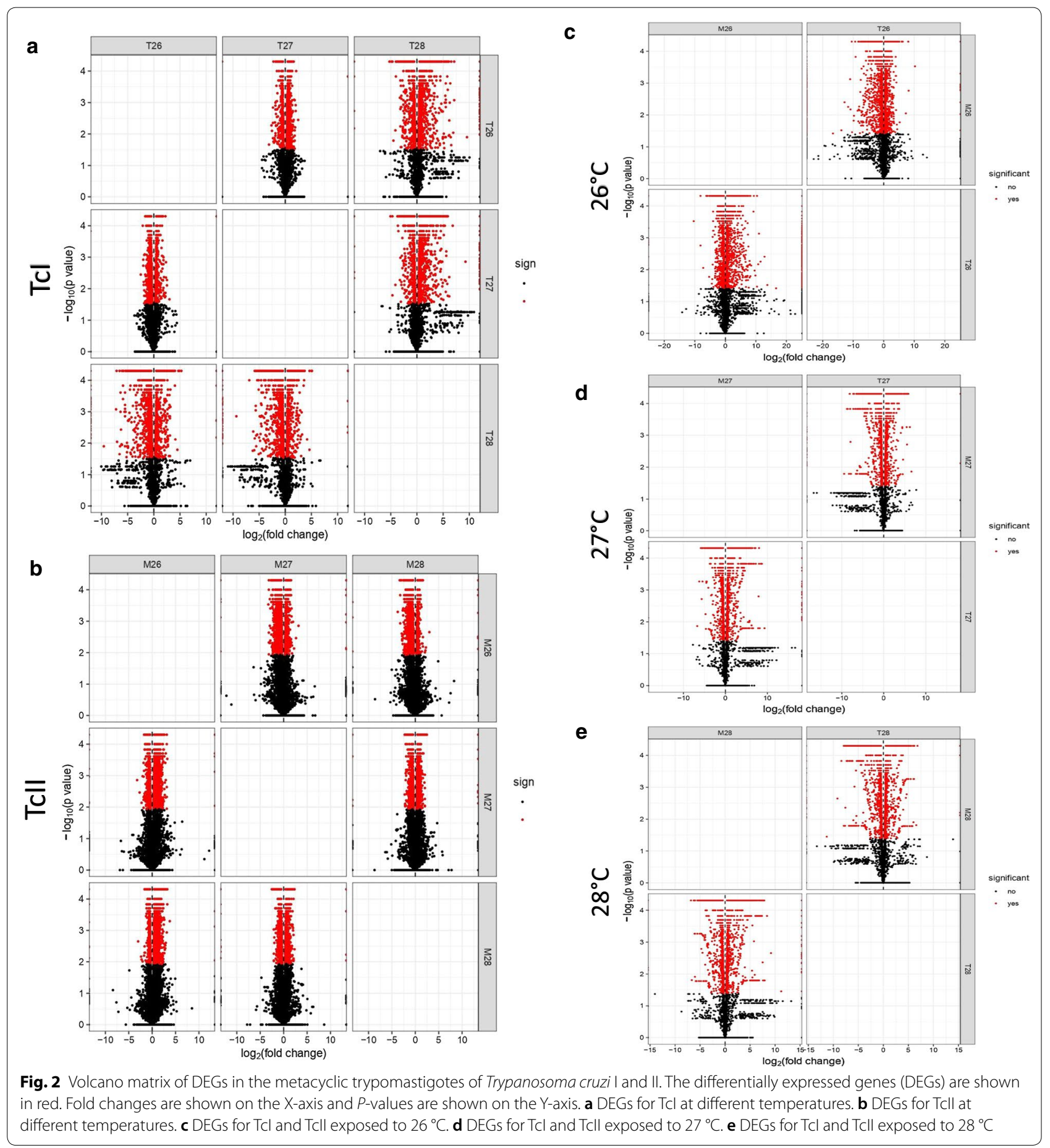


number of genes were observed when differences between MT treated with different temperatures but belonging to the same DTU were analyzed. This characteristic was even more marked when the comparison was made between DTUs that were exposed to $27^{\circ} \mathrm{C}$ and $28^{\circ} \mathrm{C}$ (Fig. 2d, e).

The TcI DTU had a greater number of downregulated genes in MT exposed to temperatures of $27^{\circ} \mathrm{C}$ and $28{ }^{\circ} \mathrm{C}$ compared with the control at $26^{\circ} \mathrm{C}$, different to what was observed for $27{ }^{\circ} \mathrm{C}$ compared with $28{ }^{\circ} \mathrm{C}$. The number of genes upregulated in TcII MT was higher for parasites exposed to $28{ }^{\circ} \mathrm{C}$ than $27{ }^{\circ} \mathrm{C}$ compared with the TcII control at $26{ }^{\circ} \mathrm{C}$ (Fig. 3a). For TcII DTU, the response to increased temperature was mainly marked by an upregulated gene expression, where the highest number of upregulated genes was observed for TcII at $28{ }^{\circ} \mathrm{C}$ (Fig. 3a).

We evaluated the presence of shared genes between different temperature treatments for each DTU. Out of a total of 10,114 expressed genes, TcI at $26{ }^{\circ} \mathrm{C}$ shared 8818 genes with TcI at $27^{\circ} \mathrm{C}$ and 9251 genes with TcI at $28^{\circ} \mathrm{C}$, and TcI at $27^{\circ} \mathrm{C}$ and $\mathrm{TcI}$ at $28^{\circ} \mathrm{C}$ shared 9711 genes (Fig. 3b). The number of genes shared between TcII at $26{ }^{\circ} \mathrm{C}$ and $27{ }^{\circ} \mathrm{C}$ was 6588 , and 6668 genes were shared with TcII at $28{ }^{\circ} \mathrm{C}$, the number of genes shared between TcII at $27{ }^{\circ} \mathrm{C}$ and $28{ }^{\circ} \mathrm{C}$ was 6768 . The temperature at which the greatest number of genes were expressed for TcI DTU was $28^{\circ} \mathrm{C}$ (Fig. 3b).

We evaluated whether there were differences between the number of upregulated and downregulated genes among the different chromosomes, and quantified the differentially expressed genes (DEGs) in each of the chromosomes for each DTU when exposed to a range of temperatures. Chromosome 1 had the highest number of upregulated and downregulated genes for the two DTUs at all of the temperatures evaluated. Many of the DEGs were found in the MT exposed to $28^{\circ} \mathrm{C}$, with DTU TcII presenting the greatest number of changes and showing an interesting pattern of downregulation, with 165 genes downregulated on chromosome 1, 96 genes downregulated on chromosome 5, 120 genes downregulated on chromosome 37, and 98 genes downregulated on chromosome 11, in addition to various changes in the remaining chromosomes. Similarly, when the upregulated genes were evaluated by chromosome, TcII at $28{ }^{\circ} \mathrm{C}$ had an average of 100 to $>300$ genes expressed in the majority of chromosomes from 1 to 21 ; however, the greatest number of upregulated genes corresponded to TcII at $27{ }^{\circ} \mathrm{C}$, and no upregulated genes were observed for TcI at $28^{\circ} \mathrm{C}$, as previously observed (Fig. 3c).

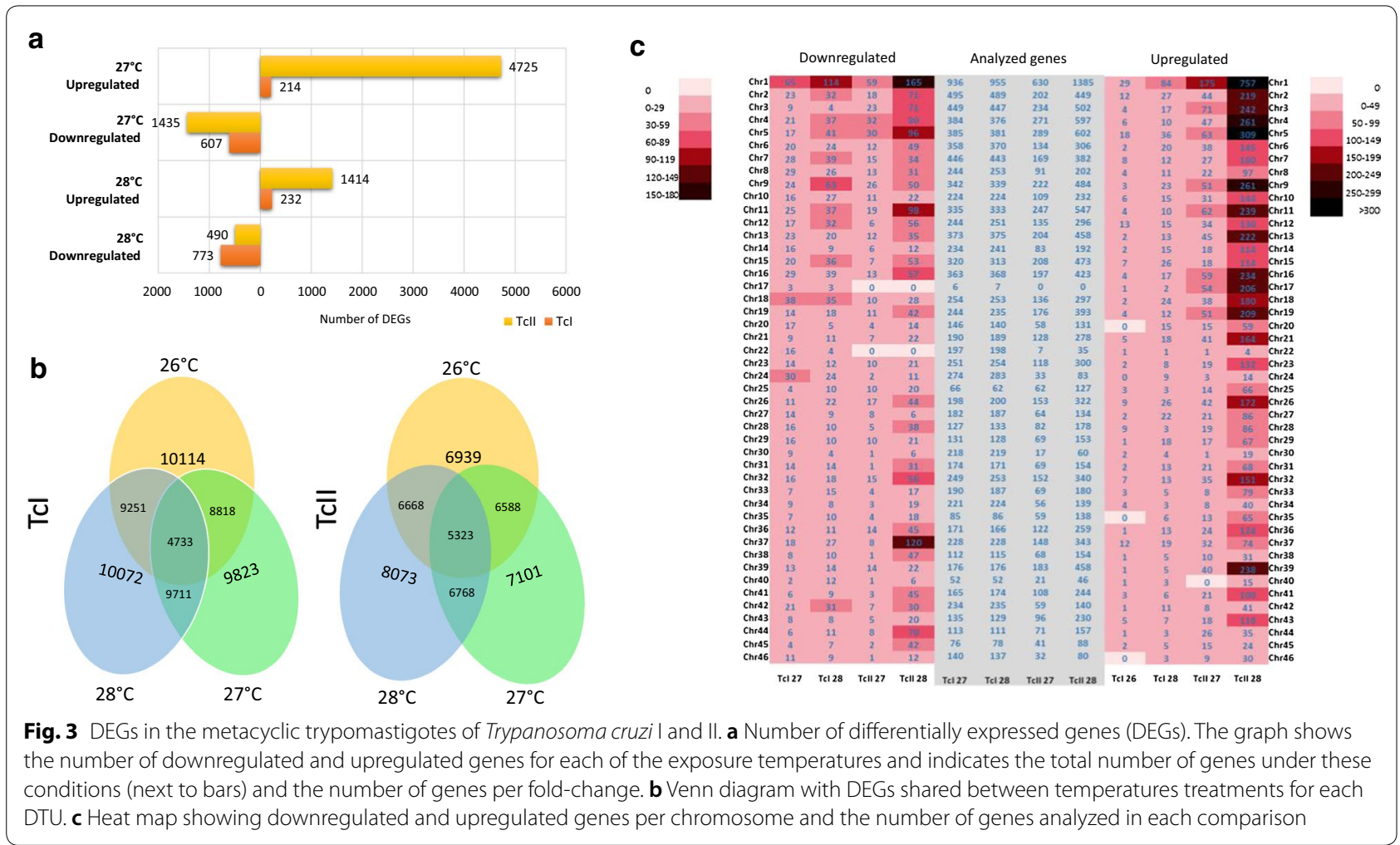




\section{Differentially expressed genes were associated with molecular processes that play an important role during thermal stress}

The IDs for each of the downregulated and upregulated genes in each of the treatments evaluated here were submitted to the Tritryp gene database of EupathDB and gene ontology analysis was performed for each DTU and temperature (Additional files 6, 7, 8: Tables S4, S5, S6). Of the downregulated genes, 607 for TcI at $27^{\circ} \mathrm{C}$ and 773 for TcI at $28^{\circ} \mathrm{C}$ were subjected to analysis; of these, a total of 463 and 625 GO terms, respectively, were obtained. Large percentages of the genes were associated with molecular processes. Of note, many genes related to oxidoreductase activity in $\mathrm{TcI}$ at $28{ }^{\circ} \mathrm{C}$ were downregulated, which is an important part of the metacyclogenesis process, and as a consequence, of the emergence of MTs. Similarly, when the terms associated with biological processes were evaluated, downregulation of genes involved in oxidationreduction processes was observed at both temperatures (Fig. 4b, c). A total of 214 and 232 overexpressed genes in TcI at $27{ }^{\circ} \mathrm{C}$ and $28{ }^{\circ} \mathrm{C}$, respectively, were evaluated for the ontological terms. The results for this group of genes showed a total of $406 \mathrm{GO}$ terms for $27{ }^{\circ} \mathrm{C}$ and 427 for
$28{ }^{\circ} \mathrm{C}$. The highest percentage of ontology terms corresponded to molecular processes, and these results were similar to those found for downregulated genes in TcI (Fig. 4a). Ontology terms relating to proteolysis processes and the phosphorylation of proteins were also observed at both temperatures, as well as genes relating to the motor activity of microtubules (Fig. 4b, c).

The most differentially upregulated and downregulated genes were associated with molecular processes based on the GO ontology for both temperatures used in TcII. A total of 1435 and 490 downregulated genes were obtained at $27{ }^{\circ} \mathrm{C}$ and $28{ }^{\circ} \mathrm{C}$, respectively; these were associated with 541 and 625 GO terms, respectively. Downregulated genes associated with GO terms involved with oxidationreduction processes and oxidoreductase activity were found at both temperatures (Fig. 5b, c). A total of 1414 and 4725 genes were upregulated in TcII at $27{ }^{\circ} \mathrm{C}$ and $28{ }^{\circ} \mathrm{C}$, respectively; of these, we found associations with 977 and 1713 GO terms, respectively, including terms associated with the upregulation of transport mediators by vesicles (Fig. 5b, c). Some of the processes with the largest number of DEGs are described below.

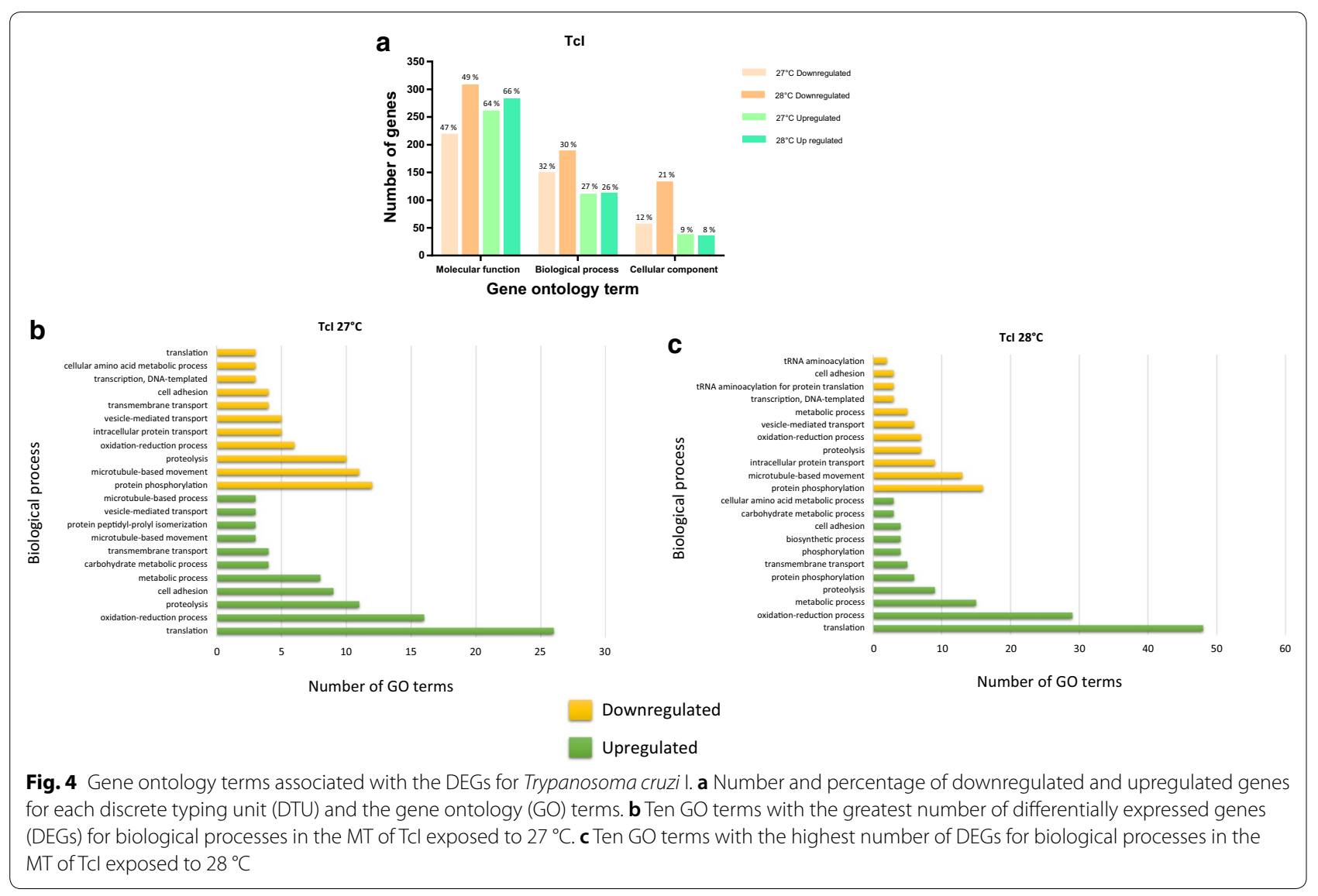


a

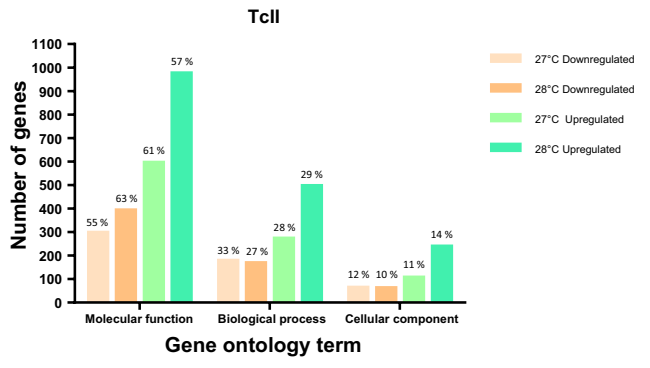

b

b

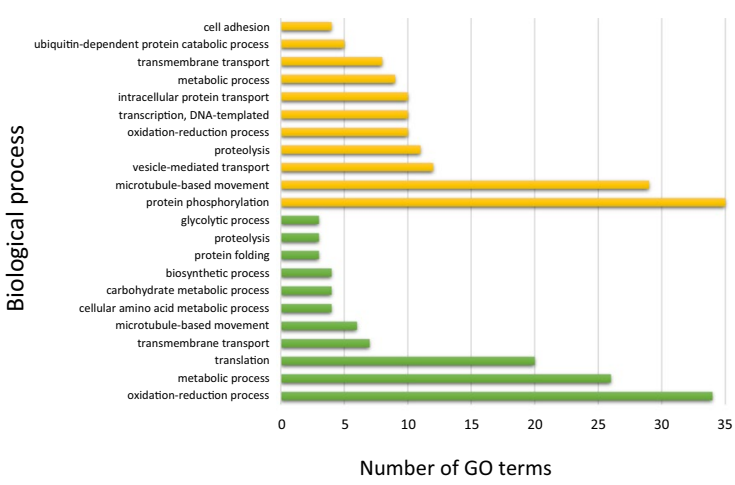

c

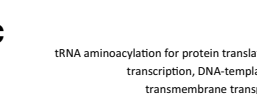

(2)

Tcll $28^{\circ} \mathrm{C}$

Downregulated

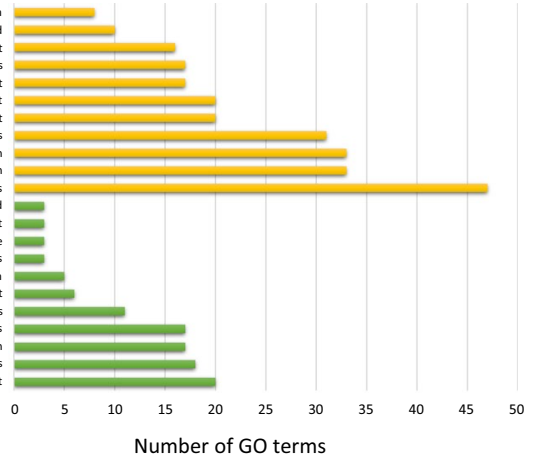

Upregulated

Fig. 5 Gene ontology terms associated with the DEGs for Trypanosoma cruzi ll. a Number and percentage of downregulated and upregulated genes for each discrete typing unit (DTU) and the gene ontology (GO) terms. b Ten GO terms with the greatest number of differentially expressed genes (DEGs) for biological processes in the MT of Tcll exposed to $27^{\circ} \mathrm{C}$. $\mathbf{c}$ Ten GO terms with the highest number of DEGs for biological processes in the MT of Tcll exposed to $28^{\circ} \mathrm{C}$

\section{Metabolism}

A high degree of regulation was observed for genes involved in the metabolism of lipids in the MT when exposed to different temperatures. The treatment with the most DEGs are involved in lipid metabolism was TcII at $27{ }^{\circ} \mathrm{C}$ with 10 downregulated genes, followed by TcI at $28^{\circ} \mathrm{C}$ with 8 downregulated genes and TcI at $27^{\circ} \mathrm{C}$ with 6 downregulated genes when compared to TcI at $26{ }^{\circ} \mathrm{C}$ (Additional files 6, 7: Table S4, S5). Common genes altered in all of these treatments were TcSYL_0078950 and TcSYL_0103620 annotated under the terms lipid metabolic process and oxidation-reduction process, respectively. In addition, genes involved in the synthesis of some amino acids, dependent on this metabolic pathway, such as arginine (TcSYL_0201940) for TcII at $27{ }^{\circ} \mathrm{C}$ and proline (TcSYL_0201810) for TcI at $28{ }^{\circ} \mathrm{C}$, were downregulated (Additional file 6: Table S4). The downregulation of a gene associated with the tetrahydrofolate biosynthetic process (log2-fold_change: - 158.836, TcSYL_0078950) in TcI at $27^{\circ} \mathrm{C}$ was also detected (Additional file 6: Table S4).

The coding transcript for the hexokinase enzyme (TcSYL_0169190-TcSYL_0169200) showed a decrease in expression for all of the treatments compared with the control. Similarly, the transcript for lactate/ malate dehydrogenase with the alpha/beta C-terminal domain (TcSYL_0122290) was upregulated for all treatments except for TcII at $28{ }^{\circ} \mathrm{C}$. Aldose 1-epimerase (TcSYL_0046290) was upregulated in MT exposed to $27{ }^{\circ} \mathrm{C}$ and in TcII at $28{ }^{\circ} \mathrm{C}$. Similar results were found for the transcript encoding glucosamine-6-phosphate isomerases/6-phosphogluconolactonase, which was upregulated for TcI at $27{ }^{\circ} \mathrm{C}$ and TcII at $28{ }^{\circ} \mathrm{C}$ (TcSYL_0165520) (Additional files 6, 7: Table S4, S5). A more in-depth analysis of glucose metabolism revealed a decrease in expression levels for genes involved in the GO terms "glucose 6-phosphate metabolic process" and "cellular glucose homeostasis" for TcI at $28{ }^{\circ} \mathrm{C}$ and TcII at $27^{\circ} \mathrm{C}$; however, the genes for the same $\mathrm{GO}$ terms were upregulated for TcII at $28{ }^{\circ} \mathrm{C}$ (Additional file 6: Table S4). The transcript TcSYL_0000660 coding for 6-phosphofructo-2-kinase involved in the GO fructose metabolic process was upregulated in most of the treatments except for TcI at $27{ }^{\circ} \mathrm{C}$ (Additional files 6, 7: Table S4, S5). 


\section{Oxidoreduction}

One of the processes most affected by the exposure of MT to different temperatures was oxidoreduction. A total of 15 transcripts for TcI at $27{ }^{\circ} \mathrm{C}, 29$ transcripts for TcI at $28{ }^{\circ} \mathrm{C}, 34$ transcripts for TcII at $27{ }^{\circ} \mathrm{C}$ and 17 transcripts for TcII at $28{ }^{\circ} \mathrm{C}$ corresponded to downregulated genes involved in the reduction-oxidation process. In addition, a small number of upregulated genes related to the reduction-oxidation process was detected for TcI at $27{ }^{\circ} \mathrm{C}$ (5 transcripts), TcI at $28{ }^{\circ} \mathrm{C}$ (7 transcripts) and TcII at $27^{\circ} \mathrm{C}$ (10 transcripts); however, 47 transcripts were detected for TcII at $28{ }^{\circ} \mathrm{C}$ (Additional files 6, 7, 8: Tables S4, S5, S6). The products for each of the downregulated and upregulated genes are available in Additional file 8: Table S6, including different types of oxidoreductases, peroxidases, hydrogenases and cytochrome B oxidases involved in this pathway.

TcI showed downregulation in the expression of genes mainly responsible for the management of oxidative stress in parasites incubated at $27^{\circ} \mathrm{C}$. Among these genes were quinone reductase (NADPH), fumarate reductase $(\mathrm{NADH})$, and cytochrome $c$ oxidase, as well as amino acid kinases and peptidases, which are indispensable for obtaining energy in the parasite during part of metacyclogenesis. TcI exposed to $28{ }^{\circ} \mathrm{C}$ showed a decrease in the expression of proteins responsible for the regulation of oxidative stress, similar to the results at $27^{\circ} \mathrm{C}$, but also showed decreased expression of other proteins such as cytochrome-b5 reductase and alcohol dehydrogenase (Additional file 8: Table S6), which indicates that the differential expression of these proteins may be a consequence of the exposure of MT to high temperatures.

\section{Proteins related to proteolysis}

Proteins related to proteolysis play an important role in the regulation, maintenance, and progression of the life-cycle of $T$. cruzi. Our results revealed the regulation of genes coding for proteins of some important families related to these processes (Additional files 6, 7, 8: Tables S4, S5, S6). The predominant family of proteins that were regulated included leishmanolysin or GP63, and a total of 8 genes were downregulated and 4 were upregulated for TcI at $27{ }^{\circ} \mathrm{C}, 4$ were downregulated and 3 were upregulated for $\mathrm{TcI}$ at $28{ }^{\circ} \mathrm{C}$, no genes were downregulated but 4 were upregulated for TcII at $27{ }^{\circ} \mathrm{C}$, and 3 were downregulated and 8 were upregulated for TcI at $28{ }^{\circ} \mathrm{C}$ (Additional files 6, 7: Table S4, $\mathrm{S} 5)$. It is important to note that although genes encoding proteins within this family were both upregulated and downregulated, none of the genes ID showed both of these outcomes indicating the specific up- or downregulation of specific GP63 proteins (Additional file 9: Table S7).
The M32 metallopeptidase family of proteins showed different expression patterns between treatments. Two transcripts were upregulated for $\mathrm{TcI}$ at $27{ }^{\circ} \mathrm{C}$ and downregulated for TcI at $28{ }^{\circ} \mathrm{C}$ (TcSYL_0019490 and TcSYL_0138670), TcSYL_0138680 being the only gene that was downregulated for $\mathrm{TcI}$ at $28{ }^{\circ} \mathrm{C}$. Regarding TcII, transcripts TcSYL_0019490 and TcSYL_0138670 were downregulated in MT exposed to both temperatures (Additional file 9: Table S7).

The calpain family of cysteine proteases was another family of proteins regulated in MT under different temperatures. The transcripts TcSYL_0080730, TcSYL_0080800, TcSYL_0080820 and TcSYL_0146610 were upregulated in TcI at $27{ }^{\circ} \mathrm{C}$, whereas for TcII at $27{ }^{\circ} \mathrm{C}$ only the TcSYL_0146610 gene was upregulated, and TcII at $28{ }^{\circ} \mathrm{C}$ showed a decrease in the expression of TcSYL_0080820 and TcSYL_0146610 genes, and an increase in expression of TcSYL_0063550 (Additional file 9: Table S7).

Finally, both thermal treatments triggered the overexpression of ubiquitin-2-like Rad60 SUMO-like (TcSYL_0109300) protein in TcII. In addition, a series of proteases were expressed differentially in some of the treatments. When evaluating $\mathrm{TcI}$ at $28{ }^{\circ} \mathrm{C}$, transcript TcSYL_0075250 coding for the cytosol aminopeptidase family was downregulated, whereas TcSYL_0202010 (M16C-associated peptidase) was upregulated (Additional file 6: Table S4). For TcII at $27{ }^{\circ} \mathrm{C}$, TcSYL_0013180 (prolyl oligopeptidase family) was overexpressed. Finally, for TcII at $28{ }^{\circ} \mathrm{C}$, TcSYL_0171200 (serine carboxypeptidase) was upregulated (Additional file 9: Table S7).

\section{Proteins related to phosphorylation}

The transcripts TcSYL_0114970 (chromosome 18) and TcSYL_0171180 (chromosome 36), both annotated as protein kinase domains, were downregulated for TcI at $27{ }^{\circ} \mathrm{C}$, and simultaneously, a total of 12 protein kinase domain transcripts were upregulated. For $\mathrm{TcI}$ at $28{ }^{\circ} \mathrm{C}$, 6 genes coding for protein kinase domains were downregulated and 12 genes were upregulated. For TcII, the same genes were downregulated and 34 were upregulated in the MT exposed to $27^{\circ} \mathrm{C}$, and 16 were downregulated and 41 were upregulated in the MT exposed to $28{ }^{\circ} \mathrm{C}$ (Additional file 10: Table S8).

\section{Translation}

One of the most disturbed processes when evaluating the GO for the DEGs in the MT exposed to different temperatures was translation. A total of 26 transcripts related to the process of translation were downregulated for TcI at $27{ }^{\circ} \mathrm{C}$ and 48 transcripts were downregulated for TcI at $28{ }^{\circ} \mathrm{C}$, compared with 6 upregulated transcripts for 
$27^{\circ} \mathrm{C}$ and 5 upregulated transcripts for $28^{\circ} \mathrm{C}$. The results obtained for TcII showed similar patterns, especially when evaluating MT exposed to $27{ }^{\circ} \mathrm{C}$, when 24 genes were downregulated and 6 genes were upregulated. By contrast, for TcII at $28{ }^{\circ} \mathrm{C}, 8$ genes were downregulated and 7 genes were upregulated (Additional file 6: Table S4, Additional file 7: Table S5).

The family of ribosomal proteins were the most affected transcripts in MT after exposure to high temperatures, with 26 transcripts upregulated for $\mathrm{TcI}$ at $27{ }^{\circ} \mathrm{C}, 44$ transcripts upregulated for $\mathrm{TcI}$ at $28{ }^{\circ} \mathrm{C}, 18$ transcripts upregulated for TcII at $27^{\circ} \mathrm{C}$ and only two transcripts upregulated for TcII at $28{ }^{\circ} \mathrm{C}$. The complete list of DEGs is available in Additional file 7: Table S5. Transcripts TcSYL_0010030 (KH domain) and TcSYL_0103320 (KOW motif) were downregulated in TcI at $28^{\circ} \mathrm{C}$ and TcII at $27^{\circ} \mathrm{C}$, tRNA synthetases of class I (M) (TcSYL_0170460) was overexpressed in TcI for both treatments and two transcripts coding for tRNA synthetases of class I (I, L, M and V) (TcSYL_0090210 and TcSYL_0140390) and two transcripts coding for mitochondrial small ribosomal subunit Rsm22 (TcSYL_0048380 and TcSYL_0048390) were upregulated in TcI at $27^{\circ} \mathrm{C}$. For TcI at $28^{\circ} \mathrm{C}$, there was an increase in the expression of TcSYL_0166880 and TcSYL_0202360, both coding for tRNA synthetases of class II (D, K and N) (Additional file 11: Table S9). Finally, the upregulated genes in TcII at $27{ }^{\circ} \mathrm{C}$ encoded families of ribosomal proteins L4/L1 (TcSYL_0003330), S4 (TcSYL_0011150), L2 (TcSYL_0013860) and L14p/ L23e (TcSYL_0046720), whereas these genes were downregulated in the other treatments. In addition, upregulation of the RNA polymerase I-associated factor PAF67 (TcSYL_0113260) was observed in TcII at $27^{\circ} \mathrm{C}$ (Additional file 11: Table S9).

\section{Vesicle-mediated transport}

Genes involved in vesicle-mediated transport were downregulated in three of the four evaluated treatments (TcI $27^{\circ} \mathrm{C}$, TcII $27{ }^{\circ} \mathrm{C}$, TcII $28^{\circ} \mathrm{C}$ ) with respect to the control. The coding transcript for vesicle-mediated transport (TcSYL_0091630) was downregulated in TcII at $27{ }^{\circ} \mathrm{C}$ and $28{ }^{\circ} \mathrm{C}$, as were genes involved in the transport of ions (TcSYL_0109340), metal ions (TcSYL_0178120), cations (TcSYL_0174330), chloride ions (TcSYL_0111950) and hydrogen ions (TcSYL_0181420). The transport of some macromolecules essential for the parasite was also affected in TcI at $27^{\circ} \mathrm{C}$ and TcII at $28^{\circ} \mathrm{C}$, with a decrease in the expression of the genes TcSYL_0146190 (protein transport) and TcSYL_0047800 (nucleoside transmembrane transport) (Additional files 6, 7: Table S4, S5).

\section{A greater number of upregulated genes observed in Tcll} than in Tcl when exposed to different temperatures When DTUs were compared between the different temperature treatments, the ontology with the highest number of downregulated and upregulated genes was related to molecular processes. When comparing between DTUs at $26{ }^{\circ} \mathrm{C}$, a total of 957 terms were downregulated in TcII compared to TcI and 810 terms were upregulated in the same comparison, this being the only temperature where the number of downregulated genes was higher than that of upregulated genes. A decrease in the expression of structural components of ribosomes and integral components of the membrane and cytoplasm was observed in TcII compared with TcI, in addition to an increase in the expression of genes that encode DNA binding proteins for this DTU (Additional file 8: Table S6). The results obtained at $27{ }^{\circ} \mathrm{C}$ revealed 1427 downregulated genes and 1274 regulated genes, and consistent with the results at $26{ }^{\circ} \mathrm{C}$, there was a decrease in the expression of genes coding for integral components of the membrane and cytoplasm, in addition to an increase in the expression of genes encoding nucleic acid binding proteins (Additional file 12: Table S10). Finally, the highest temperature evaluated in this study $\left(28{ }^{\circ} \mathrm{C}\right)$ showed a total of 1210 downregulated and 1943 upregulated terms between DTUs. Ontological terms related to proteolysis and integral membrane components were found downregulated for this analysis, whereas the upregulated ontological terms that contributed most to this comparison were related to DNA binding (Additional file 12: Table S10).

\section{Discussion}

The results of this study show how slight changes in temperature affect the gene expression of two of the most important DTUs of T. cruzi (Fig. 2, Additional file 5: Table S3). Herein, we observed how temperature decreased the concentration of MT and slowed transformation, as evident when evaluating the EMD (Fig. 1). Similar results were observed when the effect of temperature on the metacyclogenesis of T. cruzi in R. prolixus was evaluated, confirming that the parasite maintains the same biological characteristics in studies both in vivo and in vitro [14]. When TcII was exposed to $28^{\circ} \mathrm{C}$, this temperature affected the concentration of MT when compared with $26{ }^{\circ} \mathrm{C}$ for the same DTU but it was significantly downregulated in $\mathrm{TCI}$ at $28{ }^{\circ} \mathrm{C}$, potentially indicating resistance in the DTU of TcII at high temperatures. The EMD for TcII at $28{ }^{\circ} \mathrm{C}$ was lower than that of TcII at $26{ }^{\circ} \mathrm{C}$, confirming the resistance of TcII when exposed to high temperatures (Fig. 1). Previous studies evaluating the metacyclogenesis process and presence of MTs in vivo showed similar results suggesting that TcII 
parasites have adapted to high temperatures [14]. Differences between these DTUs during metacyclogenesis have already been reported in other in vitro studies, where the concentration of MT was higher compared with TcI and TcIV DTUs following exposure to high temperatures [38]. Despite this, we observed regulation of the expression of different genes between parasites treated with different temperatures and between DTUs treated at the same temperature, with fewer genes regulated between DTUs treated at the same temperature, especially for $27{ }^{\circ} \mathrm{C}$ and $28{ }^{\circ} \mathrm{C}$ (Fig. 2 a, Additional file 5: Table S3). This characteristic indicates that at higher temperatures or even under stress conditions, the parasite could decrease the expression of single genes by DTUs and increase the expression of genes associated with cell stress for cell survival purposes; however, further in-depth studies are required to confirm this, that include a greater number of biological replicates.

The analyses performed here showed that chromosome 1 harbored the majority of DEGs (Fig. 2c). Interestingly, despite the fact that the length of this chromosome exceeds $3 \mathrm{Mb}$, it comprises a higher number of housekeeping genes, unlike other chromosomes that contain a large number of repetitive genes encoding surface proteins [39]. On the other hand, the presence in the T. cruzi genome of a compartment core that mainly includes conserved and disruptive genes that cover most of the repetitive coding sequences for surface proteins, influence the unequal grouping of these proteins throughout the genome and of course on each of the chromosomes [40]. Structural changes, including copy number variations $(\mathrm{CNV})$ and single nucleotide polymorphisms, have been observed in response to environmental stimuli and as a consequence of genomic adaptations [41, 42]. Based on these results, we hypothesize that $T$. cruzi may display the same characteristic of genomic adaptation to the environment, and that consequently, in response to thermal stress, may generate structural variations as a result of genetic changes on chromosomes 1 and 3. The ability to generate mutations as a consequence of oxidative stress has already been proven in this parasite and oxidative stress is believed to be the main trigger for the generation of genetic mutations during metacyclogenesis of T. cruzi, indicating the ability of this parasite to adapt to environmental stresses [43]. However, genomic studies to assess the effect of temperature or other stress stimuli on the genome of this parasite are required to support this premise including a better annotation of the available $T$. cruzi genomes.

Genes involved in the glucose 6-phosphate metabolic process and cellular glucose homeostasis were also upregulated in TcI at $28{ }^{\circ} \mathrm{C}$ and TcII at $27^{\circ} \mathrm{C}$ (Additional files 6, 7: Table S4, S5). One of the enzymes involved in this process, glucose-6-phosphate dehydrogenase, whose function is to catalyze one of the first reactions in the pentose phosphate pathway and consequently produce $\mathrm{NADPH}$, plays an essential role during infection and the defense against oxidative stress, which is why it has also been used in the study of therapeutic targets [44, 45]. Therefore, the decrease in the expression of proteins involved in the processes in which tetrahydrofolate acid and glucose 6-phosphate play a role, may have a strong influence on the cell death that occurs in the MT of TcI at $28^{\circ} \mathrm{C}$ and TcII at $27^{\circ} \mathrm{C}$, and also on the survival of TcII at $28^{\circ} \mathrm{C}$ when these genes are upregulated.

Oxidative stress is associated with cell death; however, under normal conditions, T. cruzi has the ability to cope with oxidative stress by producing a large number of antioxidant proteins and DNA repair proteins [46-49]. Our results showed a decrease in the expression of a large number of genes involved in these processes, such as quinone reductase (NADPH), fumarate reductase (NADH), cytochrome $c$ oxidase and alcohol dehydrogenase, with these genes being more highly expressed in parasites exposed to $27^{\circ} \mathrm{C}$ (Additional file 8: Table S6). However, even more interesting is the massive increase in the number of downregulated genes relating to oxidative stress in TcI at $27{ }^{\circ} \mathrm{C}$ and $28{ }^{\circ} \mathrm{C}$ and in TcII at $27^{\circ} \mathrm{C}$, compared with the increase in upregulated genes related to this process in TcII at $28^{\circ} \mathrm{C}$ (Additional file 8: Table S6). These findings may explain the decrease in the concentration of MT at these temperatures as a result of cell death due to uncontrolled oxidative stress and the possible resistance of MT of TcII at $28^{\circ} \mathrm{C}$ when exposed to this same source of stress, potentially illustrating the ability of this parasite to manage oxidative stress and increase of expression of genes linked to this process.

The differential expression of protein kinases during metacyclogenesis has been reported [46]. In our study, an increase in the number of genes coding for these proteins was found at all of the temperatures tested for both DTUs when compared with the control; however, the most dramatic change was exhibited by TcII, with 34 and 41 upregulated genes being observed at $27{ }^{\circ} \mathrm{C}$ and $28{ }^{\circ} \mathrm{C}$, respectively (Additional file 10 : Table S8), indicating the strong influence of these proteins in this DTU as a response to thermal stress. However, the reference genome used here for mapping does not allow us to determine the type of kinases expressed; a more in-depth study of the sequences of differentially expressed transcripts may provide insight into the specific function of the proteins to be translated. The presence of mitogenactivated protein kinases (MAPKs) in T. cruzi and their participation in evasion of the immune system has been reported, and many of these proteins play a role the stress response in other eukaryotes. For example, the Smp38 
MAPK has been reported to be involved in the regulation of homeostasis in Schistosoma mansoni under oxidative stress, which is one of the main stimuli of metacyclogenesis, and may not therefore be affected by exposure to high temperatures. Protein kinases with this type of function may be upregulated in TcII as a contingency mechanism for this type of cellular stress [50,51].

One of the characteristics of metacyclogenesis is an increase in transcription and translation followed by a decrease in the forms of MT. This is a consequence of the exposure of T. cruzi to nutrient-deficient medium, which leads to higher energy requirements that are achieved mainly by protein degradation and post-translational regulation. We therefore propose that when parasites are subjected to similar types of stress, such as temperature, this same behavior may be triggered in the parasite $[25,52]$. Our findings revealed a drastic decrease in the expression of a large number of genes coding for members of the ribosome family in three of the four thermal treatments (Additional file 11: Table S9). This indicated that the decrease in the expression of constitutive ribosomal proteins, and as a consequence the synthesis of new ribosomes, is related to the exacerbated decrease in translation in TCI at $27{ }^{\circ} \mathrm{C}$ and $28{ }^{\circ} \mathrm{C}$ and TCII at $27{ }^{\circ} \mathrm{C}$ and the presence of MT forms with these particular characteristics (Additional file 11: Table S9). The presence of ribosomal profiles in which different ribosomal proteins are combined, has already been observed in Toxoplasma gondii and T. cruzi as a mechanism for translational control between different stages and for the translation of virulence factors [53]. Studies where the expression of ribosomal proteins was analyzed showed the decrease in translation efficiency in MT compared to EP for the same strain; these results demonstrate the importance of these proteins in gene regulation between different stages of the parasite, and could give us an indication of the regulation of specific profiles of ribosomal proteins in response to any type of stress, especially considering the distinctive regulation of expression that trypanosomatids present compared to other eukaryotes [54]. The decrease in transcripts of ribosomal proteins found in our study may be related to a specific profile of translational regulation associated with the response to thermal stress; however, a more detailed study is needed to confirm this.

Metalloproteases (GP63) are a family of glycosylphosphatidylinositol (GPI)-labeled proteins present in trypanosomatids whose main function is associated with virulence. Transcriptomic analyzes have shown the presence of a group of these proteins that are expressed throughout the parasite life-cycle, while approximately the remaining $50 \%$ are stage-specific [28]. Suggesting specific functions between members of this protein family, the increase in the expression of GP63 in TcII could suggest the presence of a specific group of GP63, active in response to heat stress in this DTU, with a possible influence in quick response to stress conditions. On the other hand, the importance of GP63 has been observed during the adherence of $T$. cruzi to the intestine of the vector and the binding to host cells during infection in the host, considering our results, it could be inferred that TcII when exposed at high temperatures could acquire advantages in transmission and infection and, therefore, in the progression of its life-cycle [55-57]. However, a characterization study of the GP63 class expressed in TcII must be performed in order to know the type of response to thermal stress present in this DTU.

One of the limitations of this study was that the exposure of the parasite to different temperatures was only performed for one incubation time. This was because MT do not have the capacity for replication, so it was impossible to continue their culture in axenic medium. One of our results showed an increase in genes expressed from chromosome 1; however, complete genome analysis was not performed for the parasites exposed to different temperatures, which may have provided further insights. One of the characteristics of $T$. cruzi is that its genome is largely comprised of repetitive sequences that mostly code for families of multigenic proteins. This feature makes it difficult to assemble sequenced genomes and the only reference genome currently available is for the TcI DTU, which is at the level of chromosome assembly. Our study was conducted using this genome and this is why special care had to be taken when analyzing the differential expression of genes in TcII. In some cases, manual checks were needed to avoid bias, so the availability of a reference genome for this DTU would facilitate the analysis and assembly process for future analyses for TcII. Differences between strains of the same DTU have been observed at both genomic and biological levels; although our results cannot be fully extrapolated to all populations of TcI and TcII strains, they provide a first approach to a better comprehension of the influence of temperature stress on gene expression of MT that had not been previously evaluated. Future studies must be conducted to unravel the influence of temperature on gene expression including a greater number of strains by DTU.

\section{Conclusions}

Our study showed that temperature affects T. cruzi I and II MT through regulation of the expression of genes coding for proteins involved in the metabolism of lipids and carbohydrates, the evasion of oxidative stress, proteolysis and phosphorylation processes, and also, the decrease of ribosomal proteins involved in translation, leading to cell death. However, DTU TcII exhibited greater resistance to thermal stress and greater survival, and an increase in 
genes linked to the handling of oxidative stress and the expression of the GP63 protein was detected. This could be due to an early response to these stress conditions in the TcII DTU; the results obtained for the count of MT where from day 6 at $27{ }^{\circ} \mathrm{C}$ and on day 5 at $28^{\circ} \mathrm{C}$ showed a higher concentration of MT compared to TcI. The main objective of this study was to evaluate the changes in transcriptomic profiles in TcI and TcII MT when they are subjected to thermal stress. Subsequent studies should focus on assessing how transcriptomic profiles change by using specific temperatures to which the parasites are exposed during their passage through the vector. The presence of differential stress responses in these DTUs during emergence of MT could explain the biological differentiation exhibited by these DTUs in the host, and could also indicate a possible change in the distribution and epidemiology of these DTUs with environmental temperature increases.

\section{Supplementary information}

Supplementary information accompanies this paper at https://doi. org/10.1186/s13071-020-04125-y.

Additional file 1: Table $\mathbf{S} 1$. The number of raw sequence reads for the fastaq files obtained from the sequencing of MTs.

Additional file 2: Table S2. Files of the T. cruzi reference genome Sylvio X10-2 with links for access to the fasta and gff T. cruzi Sylvio X10-2 reference files.

Additional file 3: Figure S1. RNA Quality analysis.

Additional file 4: Figure S2. Differential comparison between technical and biological replicates.

Additional file 5: Table S3. Differentially expressed genes for MT of Tcl and Tcll using the cuffdiff tool of cufflinks.

Additional file 6: Table S4. Gene ontology (GO) terms for the genes downregulated and upregulated for MT of Tcl for both treatment temperatures.

Additional file 7: Table S5. Gene ontology (GO) terms for the genes downregulated and upregulated for MT of Tcll for both treatment temperatures.

Additional file 8: Table S6. Oxidation reduction process. Gene IDs and the products for the downregulated and upregulated genes involved in oxidation reduction process for MT of Tcl and Tcll for both treatment temperatures.

Additional file 9: Table S7. Proteolysis process. Gene IDs and the products for the downregulated and upregulated genes involved in proteolysis process for MT of Tcl and Tcll.

Additional file 10: Table S8. Phosphorylation protein process. Gene IDs and the products for the downregulated and upregulated genes involved in phosphorylation protein process for MT of Tcl and Tcll.

Additional file 11: Table S9. Translation process. Gene IDs and the products for the downregulated and upregulated genes involved in translation process for MT of Tcl and Tcll.

Additional file 12: Table S10. Gene ontology (GO) terms for the downregulated and upregulated genes for the comparison between MT of TCl and Tcll for each temperature.
Abbreviations

DTU: discrete typing unit; MT: metacyclic trypomastigote; EP: epimastigotes; CAMP: cyclic amino acid phosphate; RNA: ribonucleic acid; mRNA: messenger ribonucleic acid; GP: glicoprotein; BMD: the beginning of metacyclogenesis day; DPC: days post-culture; GO: gene ontology.

\section{Acknowledgments}

We thank Martin Llewellyn and Philipp Shwabl for their support with the bioinformatic analysis. We thank Kate Fox, DPhil, from Edanz Group (https://www. edanzediting.com/ac) for editing a draft of this manuscript.

\section{Authors' contributions}

LCS performed biological analysis, RNA extraction, bioinformatics analysis and drafted the manuscript. MM and LHP supported the biological and bioinformatic analysis. GV contributed to the generation of T. cruzi strains and designed this project. FG contributed to the design of the study. JDR designed the study, coordinated the biological and bioinformatic analysis and wrote the manuscript. All authors read and approved the final manuscript.

\section{Funding}

This study was funded by the Departamento Administrativo de Ciencia, Tecnología e Innovación COLCIENCIAS, project 120465843375 contract 063-2015 (http://www.colciencias.gov.co/node/1119) to FG, GAV and JDR. The funders played no role in the study design, data collection and analysis, the decision to publish, or preparation of the manuscript. LC was funded by DIRECCIÓN ACADÉMICA (Becas de pasantías doctorales). JDR is a Latin American fellow in the Biomedical Sciences, supported by The Pew Charitable Trusts.

\section{Availability of data and materials}

Data supporting the conclusions of this article are included within the article and its additional files. All data employed in this manuscript are available in the European Nucleotide Archive (ENA) under PRJEB33521 project (https:// www.ebi.ac.uk/ena/data/view/PRJEB33521).

\section{Ethics and consent to participate}

Not applicable.

\section{Consent for publication}

Not applicable.

\section{Competing interests}

The authors declare that they have no competing interests.

\section{Author details}

${ }^{1}$ Grupo de Investigaciones Microbiológicas-UR (GIMUR), Departamento de Biología, Facultad de Ciencias Naturales, Universidad del Rosario, Bogotá, Colombia. ${ }^{2}$ Laboratorio de Investigaciones en Parasitología Tropical, Facultad de Ciencias, Universidad del Tolima, Ibagué, Colombia. ${ }^{3}$ Centro de Investigaciones en Microbiología y Parasitología Tropical (CIMPAT), Facultad de Ciencias, Universidad de Los Andes, Bogotá, Colombia.

Received: 24 January 2020 Accepted: 8 May 2020

Published online: 14 May 2020

\section{References}

1. Edenhofer O, R Pichs-Madruga Y, Sokona,E, Farahani, S, Kadner, K, Seyboth, A, et al. IPCC, Summary for policymakers. In: Climate change 2014: mitigation of climate change. Contribution of Working Group III to the fifth assessment report of the intergovernmental panel on climate change. https://www.ipcc.ch/site/assets/uploads/2018/05/SYR_AR5 FINAL_full_wcover.pdf. 2014. Accessed 12 Nov 2019.

2. Bayoh MN, Lindsay SW. Effect of temperature on the development of the aquatic stages of Anopheles gambiae sensu stricto (Diptera: Culicidae). Bull Entomol Res. 2003;93:375-81.

3. Bi Y, Yu W, Hu W, Lin H, Guo Y, Zhou XN, et al. Impact of climate variability on Plasmodium vivax and Plasmodium falciparum malaria in Yunnan Province, China. Parasit Vectors. 2013;6:357. 
4. Butterworth MK, Morin CW, Comrie AC. An analysis of the potential impact of climate change on dengue transmission in the southeastern United States. Environ Health Perspect. 2017;25:579-85.

5. Caminade C, McIntyre KM, Jones AE. Impact of recent and future climate change on vector-borne diseases. Ann NY Acad Sci. 2019;1436:157-73.

6. Carmona-Castro O, Moo-Llanes DA, Ramsey JM. Impact of climate change on vector transmission of Trypanosoma cruzi (Chagas, 1909) in North America. Med Vet Entomol. 2018;32:84-101.

7. Ceccarelli S, Rabinovich JE. Global climate change effects on Venezuela's vulnerability to Chagas disease is linked to the geographic distribution of five triatomine species. J Med Entomol. 2015;52:1333-43.

8. González C, Wang O, Strutz SE, González-Salazar C, Sánchez-Cordero $\checkmark$, Sarkar S. Climate change and risk of leishmaniasis in North America: predictions from ecological niche models of vector and reservoir species. PLoS Negl Trop Dis. 2010;19:e585.

9. McMichael AJ, Haines A. Global climate change: the potential effects on health. BMJ. 1997;315:805-9.

10. Morin CW, Comrie AC, Ernst K. Climate and denque transmission: evidence and implications. Environ Health Perspect. 2013;121:1264-72.

11. Peterson AT, Campbell LP, Moo-Llanes DA, Travi B, Gonzalez C, Ferro MC, et al. Influences of climate change on the potential distribution of Lutzomyia longipalpis sensu lato (Psychodidae: Phlebotominae). Int J Parasitol. 2017:47:667-74.

12. Garza M, Feria Arroyo TP, Casillas EA, Sanchez-Cordero V, Rivaldi CL, Sarkar S. Projected future distributions of vectors of Trypanosoma cruzi in North America under climate change scenarios. PLoS Negl Trop Dis. 2014;58:e2818.

13. Medone P, Ceccarelli S, Parham PE, Figuera A, Rabinovich JE. The impact of climate change on the geographical distribution of two vectors of Chagas disease: implications for the force of infection. Philos Trans R Soc Lond B Biol Sci. 2015;5(370):20130560.

14. Tamayo LD, Guhl F, Vallejo GA, Ramírez JD. The effect of temperature increase on the development of Rhodnius prolixus and the course of Trypanosoma cruzi metacyclogenesis. PLoS Negl Trop Dis. 2018;12:e0006735.

15. González-Rete B, Salazar-Schettino PM, Bucio-Torres MI, Córdoba-Aguilar A, Cabrera-Bravo M. Activity of the prophenoloxidase system and survival of triatomines infected with different Trypanosoma cruzi strains under different temperatures: understanding Chagas disease in the face of climate change. Parasit Vectors. 2019;12:219.

16. Zingales B, Andrade SG, Briones MR, Campbell DA, Chiari E, Fernandes O, et al. A new consensus for Trypanosoma cruzi intraspecific nomenclature: second revision meeting recommends Tcl to TcVI. Mem Inst Oswaldo Cruz. 2009;104:1051-4.

17. Zingales B, Miles MA, Campbell DA, Tibayrenc M, Macedo AM, Teixeira MM, et al. The revised Trypanosoma cruzi subspecific nomenclature: rationale, epidemiological relevance and research applications. Infect Genet Evol. 2012;12:240-53.

18. Gonçalves CS, Avila AR, de Souza W, Motta MCM, Cavalcanti DP. Revisiting the Trypanosoma cruzi metacyclogenesis: morphological and ultrastructural analyses during cell differentiation. Parasit Vectors. 2018;6(11):83.

19. Hamedi A, Botelho L, Britto C, Fragoso SP, Umaki AC, Goldenberg S, et al. In vitro metacyclogenesis of Trypanosoma cruzi induced by starvation correlates with a transient adenylyl cyclase stimulation as well as with a constitutive upregulation of adenylyl cyclase expression. Mol Biochem Parasitol. 2015;200:9-18.

20. Vanrell MC, Losinno AD, Cueto JA, Balcazar D, Fraccaroli LV, Carrillo C, et al. The regulation of autophagy differentially affects Trypanosoma cruzi metacyclogenesis. PLoS Negl Trop Dis. 2017;11:e0006049.

21. Cardoso J, Lima CDP, Leal T, Gradia DF, Fragoso SP, Goldenberg S, et al. Analysis of proteasomal proteolysis during the in vitro metacyclogenesis of Trypanosoma cruzi. PLoS One. 2011;6:e21027.

22. Fampa P, Santos AL, Ramirez MI. Trypanosoma cruzi: ubiquity expression of surface cruzi-pain molecules in TCl and TCll field isolates. Parasitol Res. 2010;107:443-7.

23. Tyler KM, Engman DM. The life cycle of Trypanosoma cruzi revisited. Int J Parasitol. 2001;31:472-81.

24. Hernandez R, Cevallos AM, Nepomuceno-Mejia T, Lopez-Villasenor I. Stationary phase in Trypanosoma cruzi epimastigotes as a preadaptive stage for metacyclogenesis. Parasitol Res. 2012;111:509-14.
25. Avila AR, Dallagiovanna B, Yamada-Ogatta SF, Monteiro-Góes V, Fragoso SP, Krieger MA, et al. Stage-specific gene expression during Trypanosoma cruzi metacyclogenesis. Genet Mol Res. 2003;2:159-68.

26. Parodi-Talice A, Monteiro-Goes V, Arrambide N, Avila AR, Duran R, Correa $A$, et al. Proteomic analysis of metacyclic trypomastigotes undergoing Trypanosoma cruzi metacyclogenesis. J Mass Spectrom. 2007;42:1422-32.

27. Belew AT, Junqueira C, Rodrigues-Luiz GF, Valente BM, Oliveira AER, Polidoro RB, et al. Comparative transcriptome profiling of virulent and non-virulent Trypanosoma cruzi underlines the role of surface proteins during infection. PLoS Pathogens. 2017;13:e1006767.

28. Berná L, Chiribao ML, Greif G, Rodriquez M, Alvarez-Valin F, Robello C. Transcriptomic analysis reveals metabolic switches and surface remodeling as key processes for stage transition in Trypanosoma cruzi. PeerJ. 2017;5:e3017.

29. Houston-Ludlam GA, Belew AT, El-Sayed NM. Comparative transcriptome profiling of human foreskin fibroblasts infected with the Sylvio and $Y$ strains of Trypanosoma cruzi. PLoS One. 2016;11:e0159197.

30. Li Y, Shah-Simpson S, Okrah K, Belew AT, Choi J, Caradonna KL, et al. Transcriptome remodeling in Trypanosoma cruzi and human cells during intracellular infection. PLoS Pathogens. 2016;12:e1005511.

31. Udoko AN, Johnson CA, Dykan A, Rachakonda G, Villalta F, Mandape $\mathrm{SN}$, et al. Early regulation of profibrotic genes in primary human cardiac myocytes by Trypanosoma cruzi. PLoS Negl Trop Dis. 2016;10:e0003747.

32. Souto RP, Fernandes O, Macedo AM, Campbell DA, Zingales B. DNA markers define two major phylogenetic lineages of Trypanosoma cruzi. Mol Biochem Parasitol. 1996;83:141-52.

33. Cruz-Saavedra L, Munoz M, Leon C, Patarroyo MA, Arevalo G, Pavia P, et al. Purification of Trypanosoma cruzi metacyclic trypomastigotes by ion exchange chromatography in sepharose-DEAE, a novel methodology for host-pathogen interaction studies. J Microbiol Methods. 2017;142:27-32.

34. Trapnell C, Pachter L, Salzberg SL. TopHat: discovering splice junctions with RNA-seq. Bioinformatics. 2009;25:1105-11.

35. Trapnell C, Roberts A, Goff L, Pertea G, Kim D, Kelley DR, et al. Differential gene and transcript expression analysis of RNA-seq experiments with TopHat and Cufflinks. Nat Protoc. 2012;7:562-78.

36. Aurrecoechea C, Barreto A, Basenko EY, Brestelli J, Brunk BP, Cade S, et al. EuPathDB: the eukaryotic pathogen genomics database resource. Nucleic Acids Res. 2017:45:D581-91.

37. Warrenfeltz S, Basenko EY, Crouch K, Harb OS, Kissinger JC, Roos DS, et al. EuPathDB: the eukaryotic pathogen genomics database resource. Methods Mol Biol. 2018;1757:69-113.

38. Kollien AH, Schaub GA. The development of Trypanosoma cruzi in triatominae. Parasitol Today. 2000;16:381-7.

39. Callejas-Hernández F, Rastrojo A, Poveda C, Gironès N, Fresno M. Genomic assemblies of newly sequenced Trypanosoma cruzi strains reveal new genomic expansion and greater complexity. Sci Rep. 2018;8:14631.

40. Bussotti G, Gouzelou E, Cortes Boite M, Kherachi I, Harrat Z, Eddaikra N, et al. Leishmania genome dynamics during environmental adaptation reveal strain-specific differences in gene copy number variation, karyotype instability, and telomeric amplification. MBio. 2018;9:e01399-418.

41. Berná L, Rodriguez M, Chiribao ML, et al. Expanding an expanded genome: long-read sequencing of Trypanosoma cruzi. Microb Genom. 2018:4:e000177.

42. Torres-Silva CF, Repolês BM, Ornelas HO, Macedo AM, Franco GR, Junho Pena SD, et al. Assessment of genetic mutation frequency induced by oxidative stress in Trypanosoma cruzi. Genet Mol Biol. 2018;41:466-74.

43. Reis-Cunha JL, Bartholomeu DC. Trypanosoma cruzi genome assemblies: challenges and milestones of assembling a highly repetitive and complex genome. Methods Mol Biol. 2019;1955:1-22.

44. Igoillo-Esteve M, Cazzulo JJ. The glucose-6-phosphate dehydrogenase from Trypanosoma cruzi: its role in the defense of the parasite against oxidative stress. Mol Biochem Parasitol. 2006;149:170-81.

45. Maugeri DA, Cannata JJ, Cazzulo JJ. Glucose metabolism in Trypanosoma cruzi. Essays Biochem. 2011:51:15-30.

46. Amorim JC, Batista M, da Cunha ES, Lucena ACR, Lima CP, Sousa K, et al. Quantitative proteome and phosphoproteome analyses highlight the adherent population during Trypanosoma cruzi metacyclogenesis. Sci Rep. 2017;29(7):9899. 
47. Machado-Silva A, Cerqueira PG, Grazielle-Silva V, Gadelha FR, Peloso Ede F, Teixeira SM, et al. How Trypanosoma cruzi deals with oxidative stress: antioxidant defence and DNA repair pathways. Mutat Res Rev Mutat Res. 2016;767:8-22.

48. Ryter SW, Kim HP, Hoetzel A, Park JW, Nakahira K, Wang X, et al. Mechanisms of cell death in oxidative stress. Antioxid Redox Signal. 2007:9:49-89.

49. Zou Y, Liu Q, Yang X, Huang HC, Li J, Du LH, et al. Label-free monitoring of cell death induced by oxidative stress in living human cells using terahertz ATR spectroscopy. Biomed Opt Express. 2018;9:14-24.

50. Avelar Ld GA, Gava SG, Neves RH, Silva MCS, Araújo N, Tavares NC, et al. Smp38 MAP kinase regulation in Schistosoma mansoni: roles in survival, oviposition, and protection against oxidative stress. Front Immunol. 2019;24:10-21.

51. Soares-Silva M, Diniz FF, Gomes GN, Bahia D. The mitogen-activated protein kinase (MAPK) pathway: role in immune evasion by trypanosomatids. Front Microbiol. 2016;24(7):183.

52. Ferreira LR, Dossin Fde M, Ramos TC, Freymuller E, Schenkman S. Active transcription and ultrastructural changes during Trypanosoma cruzi metacyclogenesis. Ann Acad Bras Cienc. 2008;80:157-66.

53. León CM, Hernández C, Montilla M, Ramírez JD. Retrospective distribution of Trypanosoma cruzi I genotypes in Colombia. Mem Inst Oswaldo Cruz. 2015;110:387-93.
54. Smircich P, Eastman G, Bispo S, Duhagon M, Guerra-Slompo E, Garat B, et al. Ribosome profiling reveals translation control as a key mechanism generating differential gene expression in Trypanosoma cruzi. BMC Genomics. 2015;16:s443.

55. Rebello KM, Uehara LA, Ennes-Vidal V, et al. Participation of Trypanosoma cruzi gp63 molecules on the interaction with Rhodnius prolixus. Parasitology. 2019;146:1075-82.

56. Kulkarni MM, Olson CL, Engman DM, McGwire BS. Trypanosoma cruzi GP63 proteins undergo stage-specific differential posttranslational modification and are important for host cell infection. Infect Immun. 2009;77:2193-200

57. Cuevas IC, Cazzulo JJ, Sánchez DO. gp63 homologues in Trypanosoma cruzi: surface antigens with metalloproteinase activity and a possible role in host cell infection. Infect Immun. 2003;71:5739-49.

\section{Publisher's Note}

Springer Nature remains neutral with regard to jurisdictional claims in published maps and institutional affiliations.
Ready to submit your research? Choose BMC and benefit from:

- fast, convenient online submission

- thorough peer review by experienced researchers in your field

- rapid publication on acceptance

- support for research data, including large and complex data types

- gold Open Access which fosters wider collaboration and increased citations

- maximum visibility for your research: over $100 \mathrm{M}$ website views per year

At BMC, research is always in progress.

Learn more biomedcentral.com/submissions 